\title{
Miocene exhumation of the granulite-eclogite of the Ama Drime range (high Himalayas) through polyphased syn-convergence normal faulting
}

\author{
Philippe Hervé Leloup ${ }^{1 *}$, Elise Kali², Nicolas Arnaud ${ }^{2}$, Gweltaz Mahéo ${ }^{1}$ and Emmanuelle Boutonnet ${ }^{1,2}$ \\ 1 Laboratoire des Sciences de la Terre, CNRS UMR 5570, Université Claude Bernard Lyon 1-ENS Lyon, 69622 Villeurbanne Cedex, FRANCE \\ 2 Géosciences Montpellier (UMR CNRS 5243), Groupe GEODE, CC 060, Université de Montpellier 2, Place Eugène Bataillon, 34095 Montpellier \\ Cedex 5, FRANCE \\ * For correspondence, email: herve.leloup@univ-lyon1.fr
}

E-W extension in southern Tibet, and related N-S normal faults, are generally interpreted as resulting from the ongoing postorogenic thinning of a hot and thick crust. It however appears that some of these faults are quite old and may results from other mechanisms.

High grade rocks have been exhumed in the core of the Ama Drime range in South Tibet. This range is bounded to the east (DingYe) and the west (Karta) by two major presently active normal faults, that also offset the STDS. The footwall of the DingYe fault consists of migmatitic, sillimanite-garnet bearing gneisses with kyanite relics intruded by deformed and undeformed leucogranites. $\mathrm{C} / \mathrm{S}$ relations show top to the east ductile normal shearing prior to the presently active brittle normal faulting. Microprobe measurements and pseudosections analysis show minimum pressures of equilibration of $13.5 \mathrm{kbar}$ and temperature $<650^{\circ} \mathrm{C}$. The gneisses first record an episode of isobaric heating up to $\sim 750^{\circ} \mathrm{C}$ leading to partial melting. This was followed by the main phase of decompression to $6 \mathrm{kbar}$ and $700^{\circ} \mathrm{C}$ during ongoing partial melting. Migmatitic gneisses SHRIMP U/Pb dating of monazite give middle Miocene ages ( $\sim 14$ $\mathrm{Ma}$ ) for partial melting, while SIMS U/Pb dating of zircons from orthogneisses of the same unit reveal ages of more than $2 \mathrm{Ga}$. P-T conditions and inherited Proterozoic ages indicate that the core of the AmaDrime belongs to the Lesser Himalayan Crystalline Series (LHCS as in Groppo et al., 2007, J Metam. Geol). 40Ar/39Ar dating suggest that the main exhumation took place prior to $\sim 13 \mathrm{Ma}$ on the eastern side of the AmaDrime.
To the east, in the hanging-wall of the DingYe fault, garnetsillimanite micaschists with staurolite relics, intercalated with deformed tourmaline-bearing leucogranites and locally intruded by un-deformed ones, are sheared top to North in relation with the overlying STDS. Paleozoic inheritance in zircons shows that the unit belong to the High Himalayan Crystalline series. P-T paths constrained by garnet isopleths show decompression and reheating from 6 to $4 \mathrm{kbar}$ and 600 to $660^{\circ} \mathrm{C}$ implying $\sim 6 \mathrm{~kb}$ of differential unroofing with respect to the core of the AmaDrime. $\mathrm{U} / \mathrm{Pb}$ SIMS dating of monazite on un-deformed and deformed leucogranites suggest a middle Miocene age $(\sim 17 \mathrm{Ma})$ for the end of the deformation associated with the STDS. 40Ar/39Ar dating suggests that the rocks cooled below $350^{\circ} \mathrm{C}$ at $\sim 14.5 \mathrm{Ma}$.

A ductile normal fault, whose age will be constrained by ongoing 40Ar/39Ar dating, also exist on the western flank of the range. The Ama Drime thus appears to be a fault-bounded anticlinorium in the prolongation of the N-S Arun fold. Uncertainties on the dating of the deformation phases leave open two main possibilities. 1) Fast exhumation of deep ( 35 $\mathrm{km})$ partially molten crustal rocks took place in less than $1 \mathrm{Myr}$, just after the end of motion on the STDS. 2) Exhumation along the N-S Ama Drime shear zones occurred at the same time than normal faulting along the E-W STDS. In any case, N-S ductile normal faults of the Ama Drime are not related to the onset of the ongoing generalized E-W extension in southern Tibet. 